Article

\title{
Recognizing Crucial Aquatic Factors Influencing Greenhouse Gas Emissions in the Eutrophication Zone of Taihu Lake, China
}

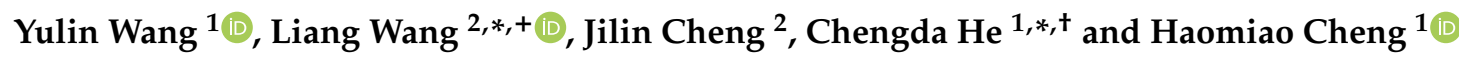 \\ 1 School of Environmental Science and Engineering, Yangzhou University, Yangzhou 225127, China; \\ wangyulin01986@126.com (Y.W.); yzchhm@yzu.edu.cn (H.C.) \\ 2 College of Hydraulic Science and Engineering, Yangzhou University, Yangzhou 225009, China; \\ jlcheng@yzu.edu.cn \\ * Correspondence: right628@126.com (W.L.); hcd@yzu.edu.cn (H.C.); Tel.: +86-15861568737 (W.L.); \\ $+86-13905275314$ (H.C.) \\ + These authors contributed equally to this work.
}

Received: 14 August 2019; Accepted: 17 September 2019; Published: 20 September 2019

\begin{abstract}
Greenhouse gas (GHG) emissions, which are closely related to climate change and serious ecological instability, have attracted global attention. The estimation of crucial aquatic factors for the flux of GHGs in lakes is a key step in controlling and reducing GHG emissions. The importance of 14 aquatic factors for GHG emissions was estimated in Meiliang Bay, which is an eutrophication shallow bay in Taihu Lake in eastern China. The random forest (RF) method, which is an improved version of the classified and regression tree (CART) model, was employed. No distribution assumption on variables was required in this method and it could include nonlinear actions and interactions among factors. The results show significant positive correlations among the fluxes of $\mathrm{CO}_{2}, \mathrm{CH}_{4}$, and $\mathrm{N}_{2} \mathrm{O}$. The most crucial factor influencing $\mathrm{CO}_{2}$ emissions is the water temperature (WT) followed by sulfate $\left(\mathrm{SO}_{4}{ }^{2-}\right)$, alkalinity (Alk), dissolved oxygen (DO), and nitrate $\left(\mathrm{NO}_{3}{ }^{-}-\mathrm{N}\right)$. The important factors for $\mathrm{CH}_{4}$ emissions are WT, $\mathrm{SO}_{4}{ }^{2-}$, $\mathrm{DO}, \mathrm{Alk}$, and $\mathrm{NO}_{2}{ }^{-}-\mathrm{N}$. The outcome for $\mathrm{N}_{2} \mathrm{O}$, in which the key factor is $\mathrm{NO}_{2}{ }^{-}-\mathrm{N}$, was slightly different from those of $\mathrm{CO}_{2}$ and $\mathrm{CH}_{4}$. A comprehensive ranking index (CRI) for the fluxes of all three GHGs was also calculated and showed that $\mathrm{WT}, \mathrm{NO}_{2}{ }^{-}-\mathrm{N}, \mathrm{SO}_{4}{ }^{2-}, \mathrm{DO}$, and Alk are the most crucial aquatic factors. These results indicate that increasing DO might be the most effective means of controlling GHG emissions in eutrophication lake bays. The role of $\mathrm{SO}_{4}{ }^{2-}$ in GHG emissions, which has previously been ignored, is also worth paying attention to. This study provides a useful basis for controlling GHG emissions in eutrophication shallow lake bays.
\end{abstract}

Keywords: GHGs; aquatic factors; random forest; water temperature; nitrogen; sulfate

\section{Introduction}

The emission of greenhouse gases (GHGs) to the atmosphere is closely related to climate change [1], resulting in significant disruption in biological living conditions and ecosystem instability [2,3]. Natural lakes, though representing only about $2 \%$ of the land surface area, are important sources of GHGs such as carbon dioxide $\left(\mathrm{CO}_{2}\right)$, methane $\left(\mathrm{CH}_{4}\right)$, and nitrous oxide $\left(\mathrm{N}_{2} \mathrm{O}\right)$ [4-6], and the emission of GHGs in lakes has therefore attracted the interest of many researchers.

According to previous assessments, lakes contribute about $71.6 \mathrm{TgC} \mathrm{CH}_{4}$ and $1943 \mathrm{TgC} \mathrm{CO}$ to the atmosphere per year [5,7-9]. However, these data remain largely uncertain due to the spatial heterogeneity of emissions in waterbodies [9,10]. Furthermore, it is even harder to estimate the contribution of $\mathrm{N}_{2} \mathrm{O}$ from global lakes [11]. In large developing countries, such as China, the problem may be more serious as data are lacking [12]. The flux of GHGs in lakes is also drastically different 
according to the distinct nutrient level zones. The $\mathrm{CH}_{4}$ flux in the East Plain Lakes zone is about two times more than in the Tibetan Plateau and Inner Mongolia-Xinjiang Lakes zone [13]. GHG emissions may be different in the same lake. Previous observations have shown a one order of magnitude larger $\mathrm{CO}_{2}$ flux in the overeutrophication zone compared with the eutrophication and mesotrophic zones in Taihu Lake in China [14]. The flux of $\mathrm{N}_{2} \mathrm{O}$ in the emergent macrophyte-type area was also about 1.5 and 30 times larger than in the algae-type and submerged macrophyte areas, respectively, during summer [15], while in winter, the flux of the algae-type area was the largest [16].

Many factors affect the flux of GHGs. Inorganic nitrogen compounds such as nitrate $[15,17,18]$ and ammonia nitrogen [19] are the factors controlling $\mathrm{N}_{2} \mathrm{O}$ production, while total phosphorus and chlorophyll A promote $\mathrm{CO}_{2}[14,20]$ and $\mathrm{CH}_{4}$ [20-22] production in waterbodies. The water temperature, wind speed, water velocity, and turbulence are common factors influencing the three kinds of GHGs [23-25]. Other factors, for instance, $\mathrm{pH}$, dissolved oxygen, and chloride ions may also affect the release of GHGs $[16,26]$. However, the roles of aquatic factors in the control of GHG emissions remain controversial because of their complex effects $[15,27,28]$. Identifying the main controlling factors and their roles is critical for further understanding the mechanisms of GHG emissions. Recognizing the aquatic variables affecting GHG emissions, especially under the nonlinear action and interaction effects of aquatic factors, is still an urgent problem to be solved.

China has 2700 lakes with a total area of $81,414.6 \mathrm{~km}^{2}$ [29]. The carbon emission of lakes in China is larger than the mean of the world lakes in the temperate zone [7]. An initial assessment showed that the lakes in China release 3.0 $\mathrm{TgC} \mathrm{CH}_{4}$ per year [13]. Controlling the GHG flux from lakes, especially from the eutrophication lake bay, will play a key role for China in meeting their United Nations Framework Convention on Climate Change (UNFCCC) commitments. It is also very important for the sustainability of lake water in a social and environmental dimension [30]. Hence, it is necessary to recognize the crucial aquatic factors influencing the GHG flux at different nutrient level zones in China, especially the eutrophication zone.

Here, we provide a combination approach to identify important variables for GHG flux in Meiliang Bay, which is an eutrophication zone of Taihu Lake in eastern China. The statistic and seasonal characteristics of 14 aquatic factors and GHG emissions in this lake bay are performed and Pearson coefficients among them are also shown. The random forest (RF) method, which can take into account the nonlinear effects and interaction effects of factors, is employed to identify the most important factors influencing the flux of the three types of GHGs. A comprehensive ranking of the GHGs is also given.

The results showed dissolved oxygen, water temperature, alkalinity and nitrite are very important for the flux of GHGs. Sulfate, which may have been ignored by previous studies, also play a crucial roles in GHG emissions. Although this assessment is based on a specific shallow lake bay, it is a useful method and its result could easily be popularized to clarify the vital factors and their roles in GHG flux in other large shallow fresh water lakes, such as Chaohu Lake [31,32] and Hongze Lake [33], in eastern of China.

\section{Methods}

\subsection{Data Sources}

Taihu Lake, which is located in the north subtropical monsoon climate region, is the third largest freshwater lake in China. It has an area of approximately $2445 \mathrm{~km}^{2}$ with a mean depth of about only 1.9 $\mathrm{m}$ [15]. There are about 100 million people living around the lake, contributing over 5 trillion dollars to the GDP in the year 2018. Shanghai, which is the most developed city in China, is also close to the lake. Hence, any research conducted on Taihu Lake could have potentially significant implications for China.

In recent decades, Taihu Lake has suffered from a eutrophication problem. The water quality in the north and east of the lake has improved, while it has deteriorated in other regions, especially 
from the 1990s to the 2010s [34,35]. The west eastern corner of the lake is Meiliang Bay, which is eutrophicated, and algae blooms occur frequently in spring and summer. Figure 1 shows the location of Taihu Lake and Meiliang Bay.

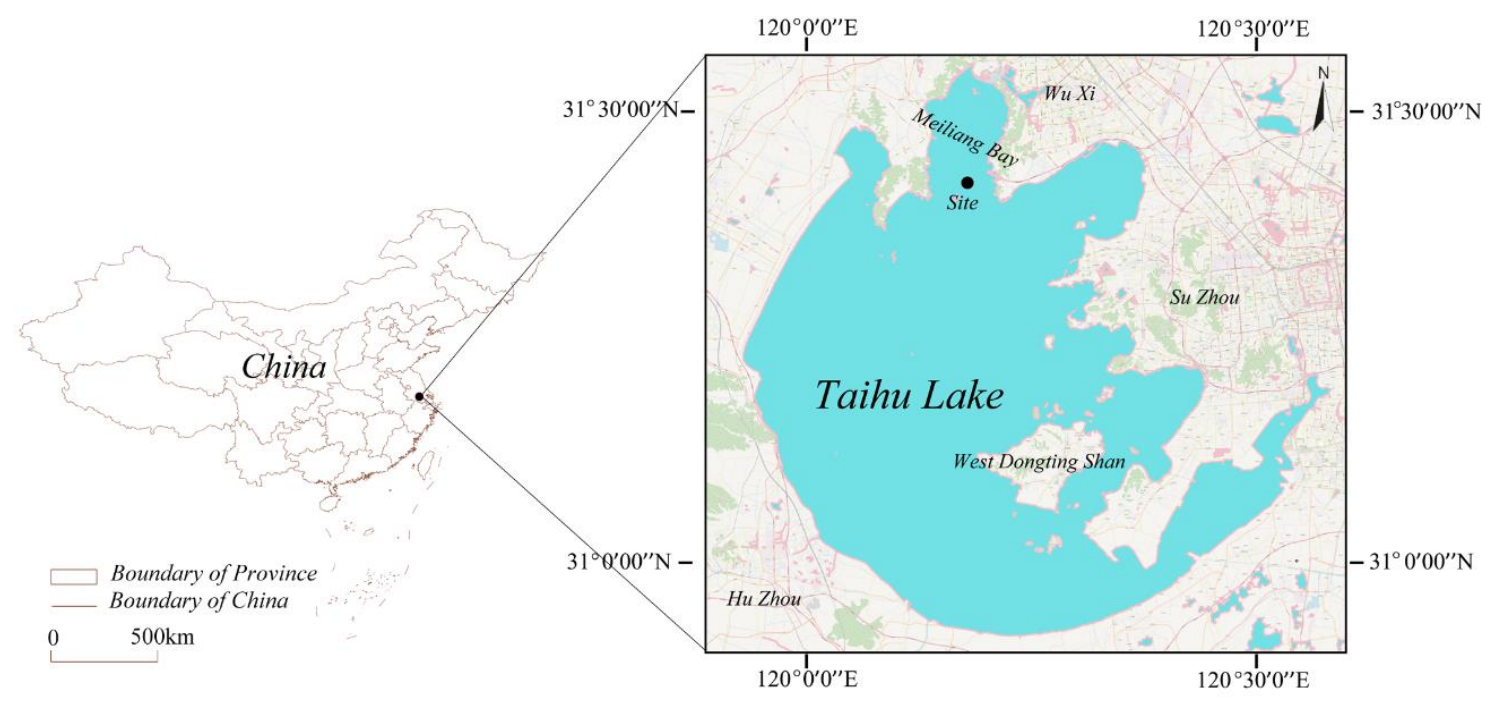

Figure 1. Location of Taihu Lake.

The research on GHG emissions carried out in this bay shows that there is considerable flux in GHGs that is significantly different from other regions in the lake [14-16]. However, only relationships between a few aquatic factors and the flux of GHGs were simultaneously considered in Meiliang Bay. The nonlinear relationships were also ignored because linear regressions and Pearson correlation analysis were applied. In this paper, the observation data of $\mathrm{CO}_{2}, \mathrm{CH}_{4}$, and $\mathrm{N}_{2} \mathrm{O}$ in this bay (Figure 1 shows the observation site) are analyzed using 14 aquatic factors, including inorganic nitrogen (nitrate, $\mathrm{NO}_{3}{ }^{-}-\mathrm{N}$; ammonia, $\mathrm{NH}_{4}{ }^{+}-\mathrm{N}$; and nitrite, $\mathrm{NO}_{2}{ }^{-}-\mathrm{N}$ ), phosphorus (phosphate, $\mathrm{PO}_{4}{ }^{3-}$; dissolved total phosphorus (dTP)), the response of nutrients (chlorophyll A,Chl-a), physical indices of water (water temperature (WT); water depth (WD); and Secchi depth (SD)) and other chemical factors (dissolved oxygen (DO); sulfate, $\mathrm{SO}_{4}{ }^{2-} ; \mathrm{O}_{2}$ demand $\left(\mathrm{COD}_{\mathrm{Mn}}\right) ; \mathrm{pH}$; and alkalinity, Alk). The data were sampled once per month from January 2004 to December 2004, and all data have been previously published [20,36].

\subsection{Statistical Analyses}

The RF method is an improved and robust version of the classified and regression tree (CART) method. It introduces the bootstrapping aggregation approach into CART [37-39] and calculates the predicted values by averaging the results of CART trees on bootstrap samples [40]. The variables used in the RF method should have an independent identical distribution [40]. However, different from the common bagging tree method, the RF method resamples prediction features at every split node to ensure independence among the selected features [41], and the scaled observations would reduce the difference in their distributions. Similar to many other statistical methods, the violation of the property of the identical distribution may not lead to serious consequences [42].

The biggest advantage of RF is that the nonlinear and interaction effects of independent variables can be included. RF has been demonstrated, through practice, to be a successful machine learning method for forecasting $[43,44]$.

Although the RF model was proposed for prediction, it can be used for other purposes. The RF model can determine the quantitative importance of predictors using some indices. The most popular index, which is also used in this paper, is an increase in node purity. The node purity was measured by 
the Gini index [38,40]. All computations were completed using the R (3.6.1) language [45] with the randomForest package.

After calculating the importance of all aquatic factors for $\mathrm{CO}_{2}, \mathrm{CH}_{4}$, and $\mathrm{N}_{2} \mathrm{O}$, a comprehensive importance index was developed to further investigate, because the significant correlations between GHG emissions were shown. The comprehensive index for all three GHGs can be given by the following equation:

$$
\begin{gathered}
R_{k}=\sum_{i=1}^{3} \frac{1}{r_{i, k}} \\
C R I=\operatorname{rank}\left(R_{k}\right)
\end{gathered}
$$

where $R_{k}$ is the index whose rank is determined as the comprehensive ranking index (CRI) for the k-th factor and $r_{i, k}$ is the importance rank of the k-th factor for the $\mathrm{i}$-th GHG. CRI is a simple, helpful, and widely used index to measure comprehensive importance [46].

\section{Results and Discussion}

As seen in Table 1, the flux of GHGs showed no significant differences to the observations in previous years for Meiliang Bay [14-16]. The minimum values of the three GHGs were lower than 0 , indicating that, at some stages, the lake acts as a sink for these GHGs, which is also in agreement with previous studies $[14,15,27]$. This induced large fluctuations of GHG emissions compared with the aquatic factors. Based on the observations of $\mathrm{CO}_{2}, \mathrm{CH}_{4}$, and $\mathrm{N}_{2} \mathrm{O}$ emissions, the coefficients of variation (CVs) were respectively 1.64, 1.50, and 1.50. These values imply that the fluxes were strongly influenced by the water environment.

Table 1. Statistics of Observations $(n=12)$.

\begin{tabular}{lllll}
\hline \multicolumn{1}{c}{ Factors } & Maximum Value & Mean Value & Minimum Value & Standard Deviation \\
\hline $\mathrm{CO}_{2}\left(\mathrm{mmol} / \mathrm{m}^{2} \mathrm{~d}\right)$ & 200.67 & 39.62 & -20.73 & 64.80 \\
$\mathrm{CH}_{4}\left(\mathrm{mmol} / \mathrm{m}^{2} \mathrm{~d}\right)$ & 2.17 & 0.54 & -0.18 & 0.81 \\
$\mathrm{~N}_{2} \mathrm{O}\left(\left(\mathrm{mmol} / \mathrm{m}^{2} \mathrm{~d}\right)\right.$ & 0.27 & 0.06 & -0.03 & 0.09 \\
$\mathrm{NO}_{3}{ }^{-}-\mathrm{N}(\mathrm{mg} / \mathrm{L})$ & 2.046 & 1.093 & 0.049 & 0.596 \\
$\mathrm{NO}_{2}{ }^{-} \mathrm{N}(\mathrm{mg} / \mathrm{L})$ & 0.146 & 0.046 & 0.006 & 0.040 \\
$\mathrm{NH}_{4}{ }^{+}-\mathrm{N}(\mathrm{mg} / \mathrm{L})$ & 1.456 & 0.507 & 0.024 & 0.577 \\
$\mathrm{PO}_{4}{ }^{-}(\mathrm{mg} / \mathrm{L})$ & 0.020 & 0.006 & 0.001 & 0.007 \\
$\mathrm{dTP}^{*}(\mathrm{mg} / \mathrm{L})$ & 0.056 & 0.027 & 0.012 & 0.015 \\
$\mathrm{Chl}^{*}{ }^{*}\left(\mathrm{mg} / \mathrm{m}^{3}\right)$ & 39.26 & 16.19 & 2.46 & 11.67 \\
$\mathrm{WT}^{*}\left({ }^{\circ} \mathrm{C}\right)$ & 29.9 & 16.7 & 4.2 & 9.0 \\
$\mathrm{WD}^{*}(\mathrm{~m})$ & 2.9 & 2.6 & 2.3 & 0.15 \\
$\mathrm{SD}^{*}(\mathrm{~m})$ & 0.80 & 0.44 & 0.30 & 0.14 \\
$\mathrm{DO}^{*}(\mathrm{mg} / \mathrm{L})$ & 12.43 & 7.98 & 6.42 & 1.99 \\
$\mathrm{SO}_{4}{ }^{2-}(\mathrm{mg} / \mathrm{L})$ & 103.60 & 2.16 & 51.60 & 0.26 \\
$\mathrm{Alk}^{*}(\mathrm{mmol} / \mathrm{L})$ & 2.60 & 4.88 & 1.76 & 0.60 \\
$\mathrm{COD}_{\mathrm{Mn}}{ }^{*}(\mathrm{mg} / \mathrm{L})$ & 5.94 & 8.18 & 4.10 & 0.13 \\
$\mathrm{pH}$ & 8.49 & 8.03 & \\
\hline
\end{tabular}

* dTP: dissolved total phosphorus, Chl-a: chlorophyll A, WT: water temperature, WD: water depth, SD: Secchi depth, DO: dissolved oxygen, Alk: alkalinity, $\mathrm{COD}_{\mathrm{Mn}}: \mathrm{O}_{2}$ demand.

The values of aquatic factors showed that the water quality was not very poor, while the high mean concentration of $\mathrm{Chl}-\mathrm{a}$ and the very low $\mathrm{SD}$ showed that eutrophication at the site was serious. The large $\mathrm{CVs}$ of $\mathrm{NH}_{4}{ }^{+}-\mathrm{N}$ and $\mathrm{NO}_{2}{ }^{-}-\mathrm{N}$, which were 1.14 and 0.87 , respectively, indicated that the release of GHGs might be affected by nitrogen. It was also observed that the concentration of $\mathrm{SO}_{4}{ }^{2-}$ in the lake, which has previously been ignored, was very high. The minimum value of $\mathrm{pH}$ was larger than 8.0, meaning the water was weakly alkaline, which would also have affected the production of $\mathrm{N}_{2} \mathrm{O}$ [47]. 
Figure 2 shows the scaled time series of the concentrations of the 14 aquatic factors and the flux in the three GHGs in the year 2004. All values were scaled by their mean and standard deviations.

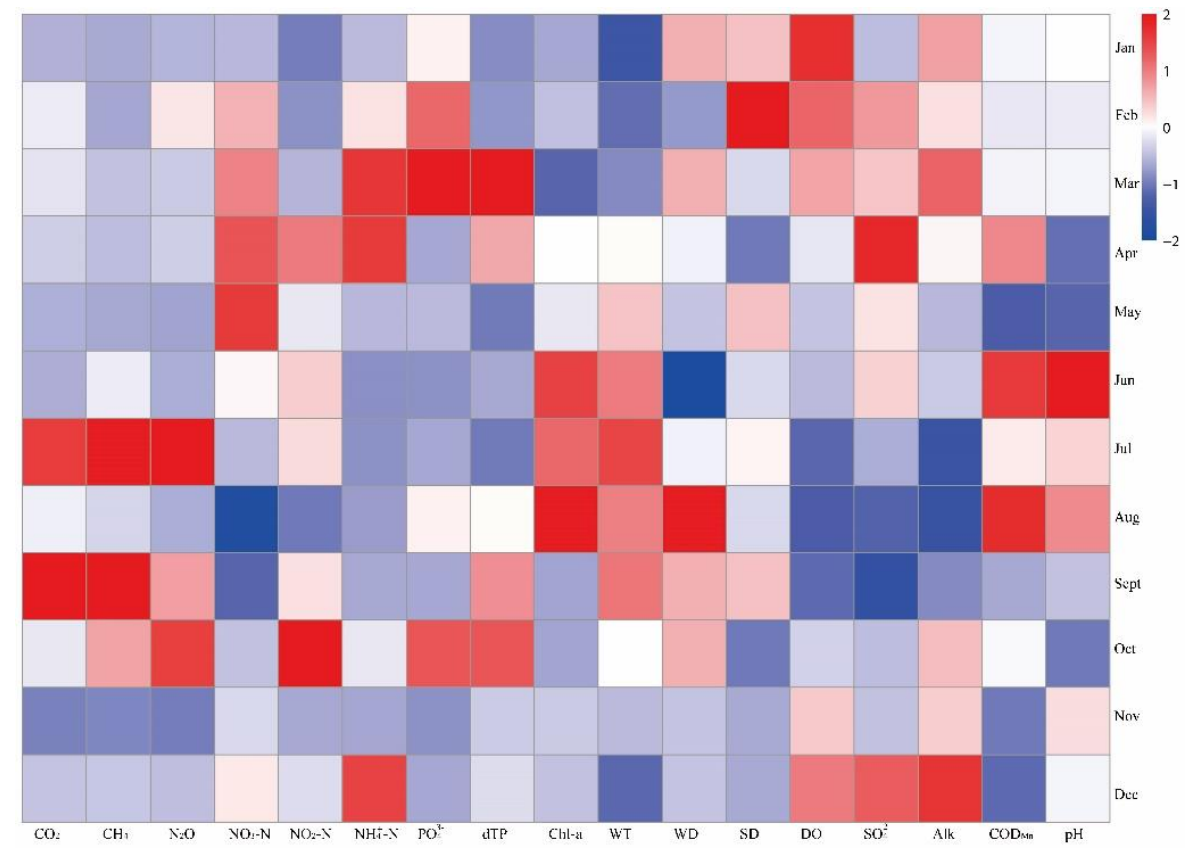

Figure 2. Scaled time series in the year 2004.

As shown in Figure 2, the GHG fluxes showed strong seasonal changes. Combined with the results of Table 1 , they progressed from one extreme to the other from winter to summer. The maximum values of flux occurred in July, and the data for $\mathrm{CH}_{4}$ and $\mathrm{CO}_{2}$ in September also showed high values, while for $\mathrm{N}_{2} \mathrm{O}$, a second peak emerged in October. November was the only month that Meiliang Bay appeared to be a sink for all three GHGs. The observed values of $\mathrm{N}_{2} \mathrm{O}$ showed slight differences to the data collected from Meiliang Bay in 2017 [15,16], but the characteristics of $\mathrm{CH}_{4}$ were in agreement with those observed in Donghu Lake in China, which is similar to Taihu Lake [28]. This difference might be because $\mathrm{N}_{2} \mathrm{O}$ is controlled by nitrogen, while $\mathrm{CH}_{4}$ emissions are not. In addition, the relatively high concentration of $\mathrm{NO}_{2}{ }^{-}-\mathrm{N}$ in October might be the reason for the high concentration of $\mathrm{N}_{2} \mathrm{O}$ observed in this month.

It was clearly observed that the water quality was better in winter, i.e., from November to January, and this can be explained by the low level of agricultural activity. The high concentrations of $\mathrm{NH}_{4}{ }^{+}-\mathrm{N}_{\text {, }}$ $\mathrm{NO}_{3}{ }^{2-}-\mathrm{N}$, and $\mathrm{SO}_{4}{ }^{2-}$ in December were notable exceptions. Laboratory experiments showed that the low temperature would decrease the activity of nitrifiers and denitrifiers $[48,49]$, and so both $\mathrm{NH}_{4}{ }^{+}-\mathrm{N}$ and $\mathrm{NO}_{3}{ }^{-}-\mathrm{N}$ accumulated. The reduction in $\mathrm{SO}_{4}{ }^{2-}$ was also weakened as the sulfate-reducing bacteria (SRB) were also influenced by low WT. References indicate that $\mathrm{SO}_{4}{ }^{2-}$ and $\mathrm{SRB}$ are closely linked to nitrogen cycling [50]; thus, the variation of $\mathrm{NH}_{4}{ }^{+}-\mathrm{N}$ and $\mathrm{NO}_{3}{ }^{2-}-\mathrm{N}$ in the time series showed the same pattern as that of $\mathrm{SO}_{4}{ }^{2-}$.

In addition to the time series, strong correlations were also observed between $\mathrm{CO}_{2}$ and $\mathrm{CH}_{4}$ and between $\mathrm{CH}_{4}$ and $\mathrm{N}_{2} \mathrm{O}$, with Pearson coefficients being significant at $p<0.01$ in Figure 3. Denitrification, acetate fermentation, and $\mathrm{CO}_{2}$ reduction, which connect the production of $\mathrm{CO}_{2}, \mathrm{CH}_{4}$, and $\mathrm{N}_{2} \mathrm{O}$ [51] could explain this outcome. The relationship between $\mathrm{N}_{2} \mathrm{O}$ and $\mathrm{CO}_{2}$ was a little less significant $(0.01<p<0.05)$. This might be because the production pathways of $\mathrm{N}_{2} \mathrm{O}$ and $\mathrm{CO}_{2}$ were not involved with each other directly. $\mathrm{SO}_{4}{ }^{2-}$ showed a negative correlation with the fluxes of $\mathrm{CO}_{2}$ and $\mathrm{CH}_{4}$ at $p<0.1$. There have been few studies on the effects of $\mathrm{SO}_{4}{ }^{2-}$ on $\mathrm{GHG}$ emissions, but those that have been done have suggested that SRB could take part in reactions with $\mathrm{CH}_{4}[52,53] . \mathrm{SO}_{4}{ }^{2-}$ would also impact the nitrogen cycle [51], which may be another reason for the significant correlation among the three GHGs. 


\begin{tabular}{|c|c|c|c|c|c|c|c|c|c|c|c|c|c|c|c|c|c|}
\hline & 1.0 & & $\begin{array}{ll}1.5 & 0.5 \\
\end{array}$ & & $\begin{array}{ll}-0.5 & 1.0\end{array}$ & & $\begin{array}{ll}.0 & 1.0 \\
\end{array}$ & & $1.5 \quad 0.5$ & & $-1 \quad 1$ & & $\begin{array}{ll}-1.5 & 0.5 \\
\end{array}$ & \multicolumn{4}{|c|}{$\begin{array}{cc}-1.0 & 1.0 \\
\end{array}$} \\
\hline $\mathrm{CO}_{2}$ & $0.92^{* * * * * 1}$ & $0.69^{*}$ & -0.43 & 0.16 & עل & -0.13 & 0.16 & 0.04 & $0.55^{*}$ & 0.26 & 0.19 & $-0.54^{*}$ & $-0.52^{*}$ & $-0.52^{*}$ & -0.06 & -0.10 & $\bar{E}$ \\
\hline & $\mathrm{CH}_{4}$ & $0.84^{* * * *}$ & -0.47 & 0.43 & -0.33 & -0.16 & 0.16 & 0.13 & $0.66^{*}$ & 0.17 & -0.04 & $-0.63^{*}$ & $-0.54^{*}$ & $-0.51^{*}$ & 0.02 & -0.03 & \\
\hline & & $\mathrm{N}_{2} \mathrm{O}$ & -0.28 & $0.56^{*}$ & -0.20 & 0.15 & 0.13 & 0.03 & 0.41 & 0.14 & 0.06 & -0.40 & -0.32 & -0.33 & -0.02 & -0.21 & \\
\hline & & & $\mathrm{NO}_{3}^{-}$ & 0.09 & $0.57^{*}$ & 0.12 & 0.01 & -0.37 & -0.34 & -0.50 & 0.08 & 0.35 & $0.80^{* * *}$ & 0.42 & -0.29 & -0.38 & \\
\hline & & & & & 0.08 & 0.04 & 0.41 & -0.08 & 0.31 & -0.10 & -0.48 & -0.36 & 0.08 & -0.01 & 0.09 & -0.32 & \\
\hline & & & & & $\mathrm{NI}_{4}^{+}-\mathrm{N}$ & 0.34 & $0.51^{*}$ & -0.47 & $-0.54^{*}$ & 0.01 & -0.21 & 0.44 & $0.77^{* *}$ & $0.68^{*}$ & -0.12 & -0.37 & \\
\hline & & & & & & $\mathrm{PO}_{4}^{3-}$ & $0.56^{*}$ & -0.43 & -0.43 & 0.34 & 0.23 & 0.34 & 0.04 & 0.37 & 0.04 & -0.21 & \\
\hline & & & & & & & dTP & -0.42 & -0.07 & 0.44 & -0.43 & -0.10 & -0.01 & 0.30 & 0.08 & -0.30 & \\
\hline & & & & & & & & Chl-a & $0.69^{*}$ & -0.06 & -0.11 & $-0.61^{*}$ & $\mid-0.20$ & $-0.72^{* * *}$ & $0.72^{* * *}$ & $0.65^{*}$ & \\
\hline & & & & & & & & & WT & 0.03 & -0.19 & $-0.97^{* * *}$ & -0.46 & $-0.88^{* * *}$ & 0.41 & 0.27 & \\
\hline & & & & & & & & & 8080 & WD & -0.16 & -0.19 & $-0.50^{*}$ & -0.18 & 0.09 & -0.35 & \\
\hline & & & & & & & & & & & SD & 0.28 & -0.05 & -0.14 & -0.16 & 0.00 & \\
\hline & & & & & & & & & & & & DO & 0.47 & $0.83^{* * *}$ & -0.37 & -0.13 & \\
\hline & & & & & & & & & & & & & $\mathrm{SO}_{4}{ }^{2-}$ & $0.56^{*}$ & -0.03 & -0.16 & \\
\hline & & & & & & & & & & & & & & Alk & -0.42 & -0.22 & \\
\hline & & & & & & & & & & & & & & 0 & CODMn & $0.58^{*}$ & \\
\hline $\begin{array}{ll}-1.0 & 1.0\end{array}$ & & $\begin{array}{l}0 \\
0\end{array}$ & & $\begin{array}{ll}.0 & 1.0\end{array}$ & & $\begin{array}{l}-0.5 \\
1.5\end{array}$ & & $1.0 \quad 1.0$ & & -2 & & $-1.0 \quad 1.0$ & - & $\begin{array}{ll}1.5 & 0.5\end{array}$ & & $-1 \quad 1$ & \\
\hline
\end{tabular}

Figure 3. The correlations among factors. The upper matrix shows the Pearson coefficients, and results were significant at ${ }^{* * *} p<0.01, * * p<0.05$, or ${ }^{*} p<0.1$ as marked. The red solid lines in the lower matrix show a smooth regression between the two factors. 
The crucial aquatic factors were similar for $\mathrm{CH}_{4}$ and $\mathrm{CO}_{2}$, with WT, DO, and Alk being recognized as key factors, which is in agreement with previous studies $[20,23,26]$. Chl-a was shown to have little effect on GHG emissions, which differs from previous research [14,20]. Having noticed that Chl-a also showed strong correlations with $\mathrm{WT}, \mathrm{DO}, \mathrm{COD}_{\mathrm{Mn}}, \mathrm{pH}$, and Alk, the weak impact that was observed might be the result of complex interactions amongst the different factors.

Few factors show a correlation with the flux of $\mathrm{N}_{2} \mathrm{O}$, with the exception of $\mathrm{NO}_{2}{ }^{-}-\mathrm{N}$. This should not be surprising considering the fact that $\mathrm{NO}_{2}{ }^{-}-\mathrm{N}$ is the intermediate product of the denitrification reaction of nitrifying bacteria [54], which produces $\mathrm{N}_{2} \mathrm{O}$ [55]. However, the effects of $\mathrm{NO}_{3}{ }^{-}$and $\mathrm{NH}_{4}{ }^{+}$ shown by some studies [15-17] may be masked by the effects of $\mathrm{NO}_{2}^{-}-\mathrm{N}$ under linear relationships. The influences of $\mathrm{SO}_{4}{ }^{2-}$ on $\mathrm{NO}_{3}{ }^{-}-\mathrm{N}$ and $\mathrm{NH}_{4}{ }^{+}-\mathrm{N}$ were very complex. The strong correlations could be explained by the effects of sulfur and sulfate on $\mathrm{NO}_{3}{ }^{-} \mathrm{N}$ reduction and $\mathrm{NH}_{4}{ }^{+}-\mathrm{N}$ oxidation [51]. We will describe and summarize these reaction details after the results of RF have been shown.

Figure 4 shows the importance of aquatic factors on the three GHGs, measured by an increase in the Gini index in the RF models. The explained variance of the three models was $80.4 \%, 86.2 \%$, and $75.1 \%$, respectively, for $\mathrm{CO}_{2}, \mathrm{CH}_{4}$, and $\mathrm{N}_{2} \mathrm{O}$, and these results imply that the $\mathrm{RF}$ models were adequate for exploring the crucial factors.

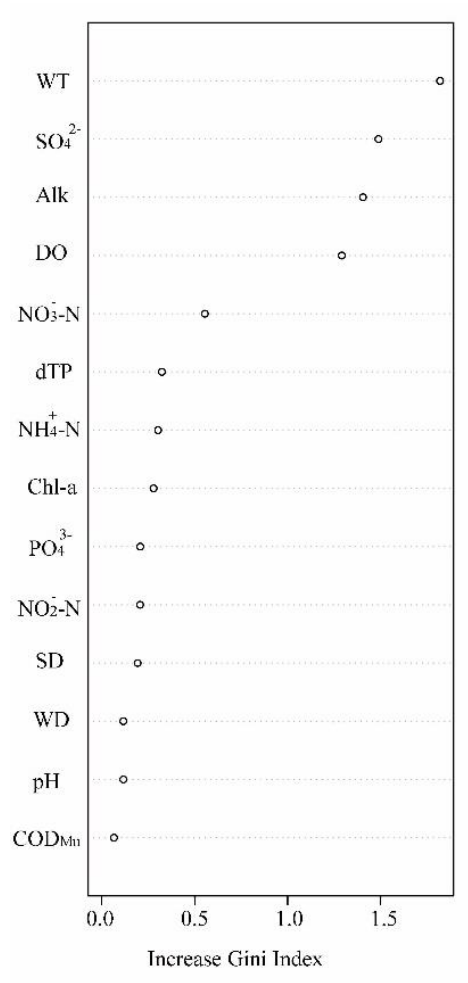

(a) $\mathrm{CO}_{2}$

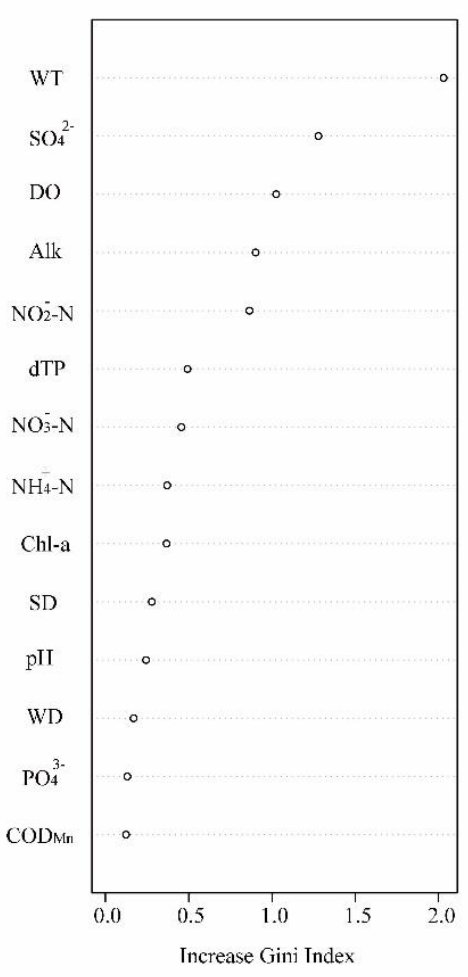

(b) $\mathrm{CH}_{4}$

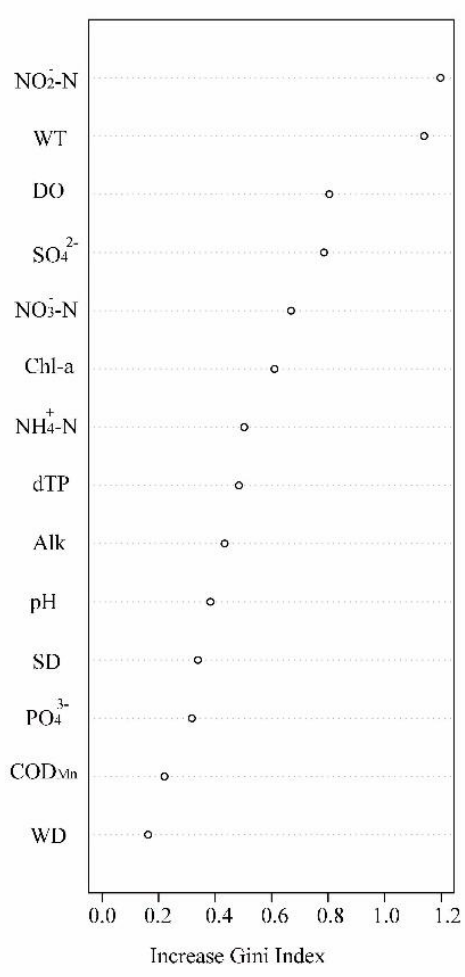

(c) $\mathrm{N}_{2} \mathrm{O}$

Figure 4. The importance order of aquatic factors for greenhouse gas (GHG) emissions using the random forest $(\mathrm{RF})$ method.

As seen in Figure 4, some RF results were in agreement with the Pearson coefficients, while others were not. The results of RF showed that the five most important aquatic factors for the three GHGs were similar. WT was the first key variable implicated in the flux of $\mathrm{CO}_{2}$ and $\mathrm{CH}_{4}$, while it was also second most important for $\mathrm{N}_{2} \mathrm{O}$ emissions. This is because methane bacteria choose different methanogen metabolic pathways [56,57] under different temperatures. The nitrifiers and denitrifiers are also sensitive to temperature [49]. This outcome was in agreement with the results of the Pearson coefficients (Figure 3) and were also analogous with the results of other field studies $[23,24,58]$. 
DO also played an important role in the emissions of the three GHGs. Methane bacteria are a diverse group of strict anaerobes [59] and are, therefore, greatly influenced by DO. The two main pathways for producing $\mathrm{CH}_{4}$, acetate fermentation and $\mathrm{CO}_{2}$ reduction, are both associated with $\mathrm{CO}_{2}[51,57]$. This may be part of the reason why $\mathrm{DO}$ also impacts $\mathrm{CO}_{2}$ production. The results of the linear correlations and field observations also confirmed the effects of DO [20,56]. In addition, the observations showed that Alk would impact the carbon dioxide partial pressure [60] and anaerobic digestion [61], so Alk greatly influences the flux of $\mathrm{CO}_{2}$ and $\mathrm{CH}_{4}$. For $\mathrm{N}_{2} \mathrm{O}$ emissions, although both nitrification and denitrification would produce $\mathrm{N}_{2} \mathrm{O}$, DO has a dominant influence in determining the pathway. This can explain the importance of $\mathrm{DO}$ for $\mathrm{N}_{2} \mathrm{O}[15,16]$.

Nitrogen compounds, including $\mathrm{NO}_{3}{ }^{-}-\mathrm{N}, \mathrm{NO}_{2}{ }^{-}-\mathrm{N}$, and $\mathrm{NH}_{4}{ }^{+}-\mathrm{N}$, were shown to be important for all three GHGs. It is easy to understand the effects of them on $\mathrm{N}_{2} \mathrm{O}$, while it should be noted that $\mathrm{NO}_{2}{ }^{-} \mathrm{N}$ was shown to be more important. This may be because, in all four main pathways, the producing $\mathrm{NO}_{2}{ }^{-}-\mathrm{N}$ are closer to $\mathrm{N}_{2} \mathrm{O}$ than $\mathrm{NO}_{3}{ }^{-}-\mathrm{N}$ [62]. Both denitrification and dissimilatory nitrogen reduction to ammonium (DNRA) oxidize organic matter and then produce $\mathrm{CO}_{2}[51,59]$, so the importance of nitrogen for $\mathrm{CO}_{2}$ can be rationalized. Methanotrophs outcompete nitrifiers for $\mathrm{O}_{2}$ when $\mathrm{CH}_{4}$ is sufficiently abundant, as more energy can be released from oxidizing methane than from oxidizing $\mathrm{NH}_{4}{ }^{+}$[51]. This is a good explanation for the negative relationship between $\mathrm{NH}_{4}{ }^{+}$and $\mathrm{CH}_{4}$ shown by the Pearson coefficients, as well as the importance of nitrogen in the results of the RF method and field observations [21].

$\mathrm{SO}_{4}{ }^{2-}$ was crucial in determining the flux of all three GHGs (Figure 4). This seemed a little strange as $\mathrm{SO}_{4}{ }^{2-}$ has been often taken for granted when assessing GHG emissions from the lake during field studies. However, the result should not be surprising. On the one hand, $\mathrm{NO}_{3}{ }^{-}$may be used in the oxidation of reduced sulfur $\left(\mathrm{S}^{0}\right.$ or $\left.\mathrm{S}^{2-}\right)$ and the production of $\mathrm{SO}_{4}{ }^{2-}$. These processes may occur in preference to DNRA and denitrification [51,59]. On the other hand, $\mathrm{SO}_{4}{ }^{2-}$ reduction by SRB could also produce $\mathrm{CO}_{2}$ [51]. Additionally, observations in freshwater wetlands indicated that $\mathrm{SO}_{4}{ }^{2-}$ input would suppress $\mathrm{CH}_{4}$ flux because of the higher energy alternative provided by $\mathrm{SO}_{4}{ }^{2-}$ reduction $[63,64]$. In summary, $\mathrm{SO}_{4}{ }^{2-}$ plays an important role in $\mathrm{CO}_{2}, \mathrm{CH}_{4}$, and $\mathrm{N}_{2} \mathrm{O}$ production.

Generally speaking, the effects of nitrogen compounds, $\mathrm{SO}_{4}{ }^{2-}$ and DO on GHG emissions is very complex and is summarized as concept models as follows.

As seen in Figure 5, the DO, WT, and ALK are conditions that affect the reactions. For example, DO determines if anaerobic or aerobic oxidation can take place, and it also chooses what type of reduction will happen. WT is also very important and it can affect the activities of SRB, nitrifiers, and denitrifiers. Different from these conditions, the $\mathrm{NO}_{3}{ }^{-}-\mathrm{N}, \mathrm{NO}_{2}{ }^{-}-\mathrm{N}, \mathrm{NH}_{4}{ }^{+}-\mathrm{N}$, and $\mathrm{SO}_{4}{ }^{2-}$ are involved with the production of GHGs directly. From the models, $\mathrm{SO}_{4}{ }^{2-}$ participates in the production of all three GHGs simultaneously, which highlights its importance and its complex effects on GHG emissions. 

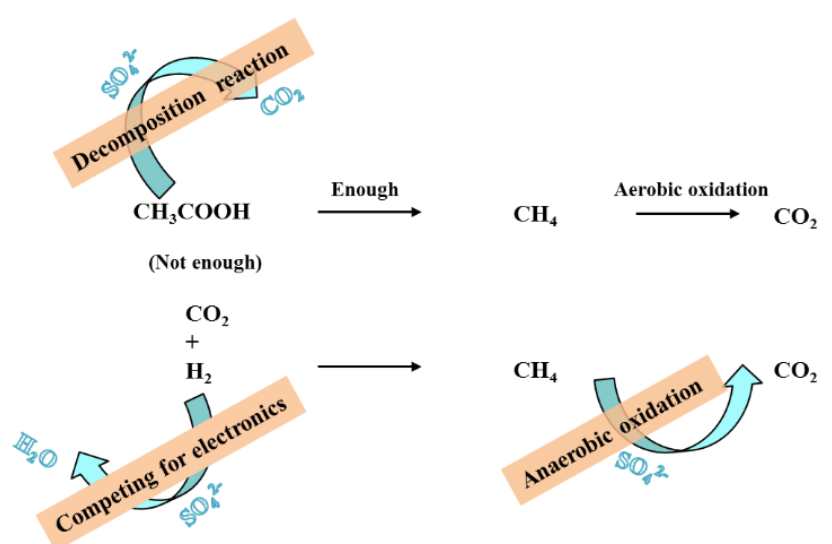

(a)

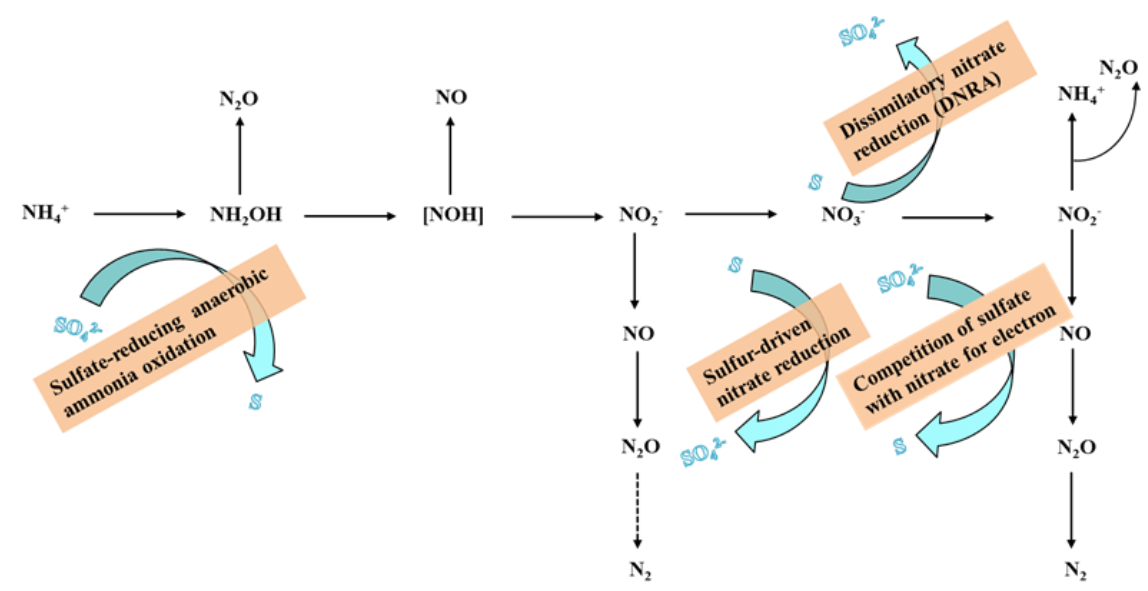

(b)

Figure 5. Concept models for GHG emissions. (a) Concept model for $\mathrm{CH}_{4}$ and $\mathrm{CO}_{2}$; (b) Concept model for $\mathrm{N}_{2} \mathrm{O}$.

The significant Pearson coefficients among $\mathrm{CO}_{2}, \mathrm{CH}_{4}$, and $\mathrm{N}_{2} \mathrm{O}$ highlight the necessity for working out a comprehensive importance index for the flux of all three GHGs. The CRI values of the five most important aquatic factors calculated by Equation 1 are shown in Table 2.

Table 2. The comprehensive importance ranking index for GHG emissions.

\begin{tabular}{lllll}
\hline Aquatic Factors & Index for $\mathbf{C O}_{\mathbf{2}}$ & Index for $\mathbf{C H}_{\mathbf{4}}$ & Index for $\mathbf{N}_{\mathbf{2}} \mathbf{O}$ & CRI* \\
\hline $\mathrm{WT}$ & 1 & 1 & 2 & 1 \\
$\mathrm{NO}_{2}{ }^{-}-\mathrm{N}$ & 10 & 5 & 1 & 2 \\
$\mathrm{SO}_{4}{ }^{--}$ & 2 & 2 & 4 & 3 \\
$\mathrm{DO}$ & 4 & 3 & 3 & 4 \\
$\mathrm{Alk}$ & 3 & 4 & 9 & 5 \\
\hline
\end{tabular}

${ }^{*}$ CRI: comprehensive ranking index defined in equation 1 .

The results of CRI showed that $\mathrm{WT}, \mathrm{NO}_{2}{ }^{-}-\mathrm{N}, \mathrm{SO}_{4}{ }^{2-}, \mathrm{DO}$, and Alk are the five most crucial aquatic factors influencing the flux of GHGs. The importance and positive relationships between WT and GHG emissions remind us that the largest flux should appear in summer. Perhaps the emissions will become larger and larger as global warming progresses [1]. $\mathrm{NO}_{2}{ }^{-}-\mathrm{N}$ is not very important for $\mathrm{CO}_{2}$ and $\mathrm{CH}_{4}$, while it is still the second crucial factors for GHG emissions because of its importance for $\mathrm{N}_{2} \mathrm{O}$ production. Compared with $\mathrm{WT}$ and $\mathrm{NO}_{2}{ }^{-}-\mathrm{N}, \mathrm{SO}_{4}{ }^{2-}$ is the third key factors for the flux of GHGs 
because of its importance in all three. Maybe this is an indication that it is feasible to control GHG emissions by increasing the concentration of $\mathrm{SO}_{4}{ }^{2-}$ in lake bays.

\section{Conclusions}

GHG emissions, which lead to serious ecological problems, have attracted widespread attention. The estimation of crucial aquatic factors in the flux of GHGs in lakes has played a key role in reducing GHG emissions. In this paper, RF methods, taking into account nonlinear effects and interaction effects of factors, were employed to identify the crucial factors among 14 aquatic variables in the flux of GHGs in a eutrophicated lake bay.

The results showed significant positive correlations between the fluxes of $\mathrm{CO}_{2}$ and $\mathrm{CH}_{4}$, which were shown to be affected by similar factors, while there was little difference for $\mathrm{N}_{2} \mathrm{O}$. WT, $\mathrm{SO}_{4}{ }^{2-}$, Alk, $\mathrm{DO}$, and $\mathrm{NO}_{3}{ }^{-}-\mathrm{N}$ were identified as the five key factors in $\mathrm{CO}_{2}$ emissions, while for $\mathrm{CH}_{4}$, the key factors were $\mathrm{WT}, \mathrm{SO}_{4}{ }^{2-}, \mathrm{DO}, \mathrm{Alk}$, and $\mathrm{NO}_{2}{ }^{-}-\mathrm{N}$. The outcome that $\mathrm{NO}_{2}{ }^{-}-\mathrm{N}$ is the most crucial factor for $\mathrm{N}_{2} \mathrm{O}$ emissions while $\mathrm{NO}_{3}{ }^{-}-\mathrm{N}$ is the fifth showed the importance of nitrogen in the flux of $\mathrm{N}_{2} \mathrm{O}$. Apart from these common factors, $\mathrm{SO}_{4}{ }^{2-}$, which has been previously ignored, was also shown to play an important role in GHG emissions. It is the second most influential factor for $\mathrm{CO}_{2}$ and $\mathrm{CH}_{4}$, and the fourth factor for $\mathrm{N}_{2} \mathrm{O}$. The concept models showed that $\mathrm{SO}_{4}{ }^{2-}$ had very complex effects on the production of $\mathrm{CO}_{2}$ and $\mathrm{CH}_{4}$, as well as on the nitrogen cycle.

The outcomes of the comprehensive ranking index for the flux of all three GHGs have also been shown. WT, $\mathrm{NO}_{2}{ }^{-}-\mathrm{N}, \mathrm{SO}_{4}{ }^{2-}, \mathrm{DO}$, and Alk were found to be the five most crucial aquatic factors. Compared with WT and Alk, the remaining factors are easier to manage by engineered measures. A comprehensive analysis of the results show that increasing the DO might be the most effective way of controlling GHG emissions in eutrophication lakes. Apart from the direct benefits of increasing DO, such as reducing the fluxes of $\mathrm{CO}_{2}$ and $\mathrm{CH}_{4}, \mathrm{~N}_{2} \mathrm{O}$ emissions should also reduce, led by the decrease in the concentration of $\mathrm{NO}_{2}{ }^{-}-\mathrm{N}$. It seems that a higher $\mathrm{SO}_{4}{ }^{2-}$ concentration would also be good for decreasing GHG emissions, but this can be a dilemma for water quality managers because there is evidence that excess $\mathrm{SO}_{4}{ }^{2-}$ can lead to black blooms in shallow lakes [65].

This study provides useful information for controlling GHG emissions in eutrophicated shallow lake bays. However, there is still work to be done. The quantitative mechanism model for water factors and GHG emissions in shallow lake bays is a very important topic for GHG emission reduction. This model will become more detailed as research continues. The smooth linear regression in Figure 3 suggests that there are threshold points for these relationships. The existence of threshold points indicates the necessity of investigating these crucial factors in GHG emissions using advanced methods. The role of $\mathrm{SO}_{4}{ }^{2-}$ should also receive more attention in future studies.

Author Contributions: Yulin Wang conducted the research and completed the first manuscript of the paper. Liang Wang and Chengda He guided the research and improved the manuscript. Haomiao Cheng and Jilin Cheng collected the data and created the figures.

Funding: This work was financially supported by the National Key R \& D Program of China (Grant No.2017YFC0403205), the National Natural Science Foundation of China (Grant Nos. 51909230 and 51809226), the China Postdoctoral Science Foundation Funded Project (Grant No. 2018M632390), the Jiangsu Planned Projects for Postdoctoral Research Funds (Grant No.2018K124C), and the Jiangsu Funded Recruitment of Postdoctoral Project (Grant No. 2018Z051).

Conflicts of Interest: The authors declare no conflict of interest.

\section{References}

1. Pachauri, R.K.; Allen, M.R.; Barros, V.R.; John, B. Climate Change 2014: Synthesis Report. Contribution of Working Groups I, II and III to the Fifth Assessment Report of the Intergovernmental Panel on Climate Change; IPCC: Geneva, Switzerland, 2014.

2. Panel, A.C.S. What We Know: The Reality, Risks and Response to Climate Change; American Association for the Advancement of Science: Washington, DC, USA, 2014. 
3. Pimm, S.L. Climate Disruption and Biodiversity. Cur. Biol. 2009, 19, R595-R601. [CrossRef] [PubMed]

4. Abril, G.; Bouillon, S.; Darchambeau, F.; Teodoru, C.R.; Marwick, T.R.; Tamooh, F.; Ochieng Omengo, F.; Geeraert, N.; Deirmendjian, L.; Polsenaere, P. Technical Note: Large Overestimation of $\mathrm{PCO}_{2}$ Calculated from $\mathrm{pH}$ and Alkalinity in Acidic, Organic-Rich Freshwaters. Biogeoscience 2015, 12, 67-78. [CrossRef]

5. Bastviken, D.; Cole, J.; Pace, M.; Tranvik, L. Methane Emissions from Lakes: Dependence of Lake Characteristics, Two Regional Assessments, and a Global Estimate. Glo. Biol. Cyc. 2004, 18, GB4009. [CrossRef]

6. Meybeck, M. Riverine Transport of Atmospheric Carbon: Sources, Global Typology and Budget. Water Air Soil Pollut. 1993, 70, 443-463. [CrossRef]

7. Bastviken, D.; Tranvik, L.J.; Downing, J.A.; Crill, P.M.; Enrich-Prast, A. Freshwater Methane Emissions Offset the Continental Carbon Sink. Science 2011, 331, 50. [CrossRef] [PubMed]

8. Aufdenkampe, A.K.; Mayorga, E.; Raymond, P.A.; Melack, J.M.; Doney, S.C.; Alin, S.R.; Aalto, R.E.; Yoo, K. Riverine Coupling of Biogeochemical Cycles between Land, Oceans, and Atmosphere. Front. Ecol. Environ. 2011, 9, 53-60. [CrossRef]

9. Tranvik, L.J.; Downing, J.A.; Cotner, J.B.; Loiselle, S.A.; Striegl, R.G.; Ballatore, T.J.; Dillon, P.; Finlay, K.; Fortino, K.; Knoll, L.B. Lakes and Reservoirs as Regulators of Carbon Cycling and Climate. Limnol. Oceanogr. 2009, 54, 2298-2314. [CrossRef]

10. Raymond, P.A.; Hartmann, J.; Lauerwald, R.; Sobek, S.; McDonald, C.; Hoover, M.; Butman, D.; Striegl, R.; Mayorga, E.; Humborg, C. Global Carbon Dioxide Emissions from Inland Waters. Nature 2013, 503, 355-359. [CrossRef] [PubMed]

11. Huttunen, J.T.; Alm, J.; Liikanen, A.; Juutinen, S.; Larmola, T.; Hammar, T.; Silvola, J.; Martikainen, P.J. Fluxes of Methane, Carbon Dioxide and Nitrous Oxide in Boreal Lakes and Potential Anthropogenic Effects on the Aquatic Greenhouse Gas Emissions. Chemosphere 2003, 52, 609-621. [CrossRef]

12. Yang, L.; Lu, F.; Zhou, X.P.; Wang, X.K.; Duan, X.N.; Sun, B.F. Progress in the Studies on the Greenhouse Gas Emissions from Reservoirs. Acta Ecol. Sinic. 2014, 34, 204-212. [CrossRef]

13. Yang, H.; Xie, P.; Ni, L.; Flower, R.J. Underestimation of $\mathrm{CH}_{4}$ Emission from Freshwater Lakes in China. Environ. Sci. Tech. 2011, 45, 4203-4204. [CrossRef] [PubMed]

14. Fan, C.X.; Phillip, W.F.; Hu, W.P.; Qin, B.Q. Divergence of Carbon Dioxide Fluxes in Different Trophic Areas of Taihu Lake, China. J. Environ. Sci. 2003, 15, 433-442.

15. Zheng, X.L.; Wen, S.L.; Li, X.; Gong, W.Q.; Liu, D.H.; Zhong, J.C. Characteristics of $\mathrm{N}_{2} \mathrm{O}$ Release and Influencing Factors in Grass-Type and Algae-Type Zones of Taihu Lake During Summer. Environ. Sci. 2018, 39, 2306-2315.

16. Zheng, X.L.; Liu, M.; Wen, S.L.; De Hong, L.; Zhong, J.C. Characteristics of $\mathrm{N}_{2} \mathrm{O}$ Formation and Emission in Algae and Grasstype Zones in Lake Taihu in Winter. Chin. Environ. Sci. 2018, 38, 683-693.

17. Beaulieu, J.J.; Tank, J.L.; Hamilton, S.K.; Wollheim, W.M.; Hall, R.O.; Mulholland, P.J.; Peterson, B.J.; Ashkenas, L.R.; Cooper, L.W.; Dahm, C.N. Nitrous Oxide Emission from Denitrification in Stream and River Networks. PNAS 2011, 108, 214-219. [CrossRef] [PubMed]

18. Herrman, K.S.; Bouchard, V.; Moore, R.H. Factors Affecting Denitrification in Agricultural Headwater Streams in Northeast Ohio, USA. Hydrobiologia 2008, 598, 305-314. [CrossRef]

19. Zhao, Y.; Xia, Y.; Kana, T.M.; Wu, Y.; Li, X.; Yan, X. Seasonal Variation and Controlling Factors of Anaerobic Ammonium Oxidation in Freshwater River Sediments in the Taihu Lake Region of China. Chemosphere 2013, 93, 2124-2131. [CrossRef]

20. Lia, S.; Bush, R.T.; Santos, I.R.; Zhang, Q.; Song, K.; Mao, R.; Wen, Z.; Lu, X.X. Large Greenhouse Gases Emissions from China's Lakes and Reservoirs. Water Res. 2018, 147, 13-24. [CrossRef]

21. Wang, X.; He, Y.; Yuan, X.; Chen, H.; Peng, C.; Yue, J.; Zhang, Q.; Diao, Y.; Liu, S. Greenhouse Gases Concentrations and Fluxes from Subtropical Small Reservoirs in Relation with Watershed Urbanization. Atmos. Environ. 2017, 154, 225-235. [CrossRef]

22. Wang, X.; He, Y.; Chen, H.; Yuan, X.; Peng, C.; Yue, J.; Zhang, Q.; Zhou, L. Ch ${ }_{4}$ Concentrations and Fluxes in a Subtropical Metropolitan River Network: Watershed Urbanization Impacts and Environmental Controls. Sci. Total Environ. 2018, 622, 622-623. [CrossRef]

23. Huang, W.; Bi, Y.; Hu, Z.; Zhu, K.; Zhao, W.; Yuan, X.; Huang, W.; Bi, Y.; Hu, Z.; Zhu, K. Spatio-Temporal Variations of GHG Emissions from Surface Water of Xiangxi River in Three Gorges Reservoir Region. China Ecol. Eng. 2015, 83, 28-32. [CrossRef] 
24. Schrier-Uijl, A.P.; Veraart, A.J.; Leffelaar, P.A.; Berendse, F.; Veenendaal, E.M. Release of $\mathrm{CO}_{2}$ and $\mathrm{CH}_{4}$ from Lakes and Drainage Ditches in Temperate Wetlands. Biogeochemistry 2011, 102, 265-279. [CrossRef]

25. Zappa, C.J.; Raymond, P.A.; Terray, E.A.; McGillis, W.R. Variation in Surface Turbulence and the Gas Transfer Velocity over a Tidal Cycle in a Macro-Tidal Estuary. Estuaries 2003, 26, 1401-1415. [CrossRef]

26. Audrey, C.; Del Giorgio, P.A. Patterns in $\mathrm{CH}_{4}$ and $\mathrm{CO}_{2}$ Concentrations across Boreal Rivers: Major Drivers and Implications for Fluvial Greenhouse Emissions under Climate Change Scenarios. Glob. Chang. Biol. 2014, 20, 1075-1088.

27. Kling, G.W.; Kipphut, G.W.; Miller, M.C. The Flux of $\mathrm{CO}_{2}$ and $\mathrm{CH}_{4}$ from Lakes and Rivers in Arctic Alaska. Hydrobiologia 1992, 240, 23-36. [CrossRef]

28. Xing, Y.P.; Xie, P.; Yang, H.; Ni, L.Y.; Wang, Y.S.; Rong, K.W. Methane and Carbon Dioxide Fluxes from a Shallow Hypereutrophic Subtropical Lake in China. Atmos. Environ. 2005, 39, 5532-5540. [CrossRef]

29. Ma, R.H.; Yang, G.S.; Duan, H.T.; Jiang, J.H.; Wang, S.M.; Feng, X.Z.; Nong, L.A.; Kong, F.X.; Xue, B.; Wu, J.L. China's Lakes at Present: Number, Area and Spatial Distribution. Sci. China Earth Sci. 2011, 54, 283-289. [CrossRef]

30. Rui, C.M.; Cruz, N.F.D.; Pires, J. Measuring the Sustainability of Urban Water Services. Environ. Sci. Policy 2015, 54, 142-151.

31. Yang, L.; Lei, K.; Meng, W.; Fu, G.; Yan, W. Temporal and Spatial Changes in Nutrients and Chlorophyll-A in a Shallow Lake, Lake Chaohu, China: An 11-Year Investigation. J. Environ. Sci. 2013, 25, 1117-1123. [CrossRef]

32. Wang, Y.L.; Lin, H.Z.; Liang, W. Sensitivity Analysis of the Chaohu Lake Eutrophication Model with New Index Based on Morris Method. Water Sci. Tech. Water Suppl. 2018, 18, 1375-1387. [CrossRef]

33. Li, S.; Guo, W.; Mitchell, B. Evaluation of Water Quality and Management of Hongze Lake and Gaoyou Lake Along the Grand Canal in Eastern China. Environ. Monitor Assess. 2011, 176, 373-384. [CrossRef] [PubMed]

34. Wang, L.; Wang, Y.L.; Cheng, H.M.; Cheng, J.L. Estimation of the Nutrient and Chlorophyll a Reference Conditions in Taihu Lake Based on a New Method with Extreme-Markov Theory. Int. J. Environ. Res. 2018, 15, 2372. [CrossRef] [PubMed]

35. Qin, B.Q. Lake Taihu, China-Dynamics and Environmental Change; Springer: London, UK, 2008.

36. Qin, B.Q.; Hu, C.H.H. Chinese Ecosystem Positioning Observation and Research Data Sets: Taihu Lake; Agriculture Press: Beijing, China, 2010.

37. Speybroeck, N. Classification and Regression Trees. Int. J. Pub. Health 2012, 57, 243-246. [CrossRef] [PubMed]

38. Song, Q. Environmental and Ecological Statistics with R, 2nd ed.; CRC Press: Boca Raton, FL, USA, 2017.

39. Huo, S.; Ma, C.; Xi, B.; He, Z.; Jing, S.; Wu, F. Nonparametric Approaches for Estimating Regional Lake Nutrient Thresholds. Ecol. Indic. 2015, 58, 225-234. [CrossRef]

40. Breiman, L. Random Forests. Mach. Learn. 2001, 45, 5-32. [CrossRef]

41. Miguel Forte, R. Mastering Predictive Analytics with R; Packt Publishing: Birmingham, UK, 2015.

42. Hastie, T.; Tibshirani, R.; Friedman, J. The Elements of Statistical Learning: Data Mining, Inference, and Prediction, 2nd ed.; Springer: New York, NY, USA, 2009.

43. Arnab, B.; Surinder, S.K.; Debasish, S.; Harmandeep, S.; Anu, K.; Sandeep, S. Potential Indicators of Soil Health Degradation in Different Land Use-Based Ecosystems in the Shiwaliks of Northwestern India. Sustainability 2019, 11, 3908.

44. Svetnik, V.; Liaw, A.; Tong, C.; Culberson, J.C.; Sheridan, R.P.; Feuston, B.P. Random Forest: A Classification and Regression Tool for Compound Classification and QSAR Modeling. J. Chem. Inf. Comput. Sci. 2003, 43, 1947. [CrossRef]

45. R Development Core Team. R: A Language and Environment for Statistical Computing; R Foundation for Statistical Computing: Austria, Vienna, 2016.

46. Saltelli, A.; Ratto, M.; Andres, T.; Campolongo, F.; Cariboni, J.; Gatelli, D.; Saisana, M.; Tarantola, S. Global Sensitivity Analysis; The Primer: New York, NY, USA, 2008.

47. Chen, H.; Mothapo, N.V.; Shi, W. Soil Moisture and pH Control Relative Contributions of Fungi and Bacteria to $\mathrm{N}_{2} \mathrm{O}$ Production. Micro Ecol. 2015, 69, 180-191. [CrossRef]

48. Wei, X.H.; Bi, X.J.; Yin, Z.X.; Zhou, X.L.; Xu, C.L.; Wen, J.G. Effects of Temperature and Dissolved Oxygen on Nitrification and Denitrification in MBBR System. China Environ. Sci. 2019, 39, 612-618.

49. Schulthess, R.V.; Kühni, M.; Gujer, W. Release of Nitric and Nitrous Oxides from Denitrifying Activated Sludge. Water Res. 1995, 29, 215-226. [CrossRef] 
50. Zhu, J.; He, Y.; Zhu, Y.; Huang, M.; Zhang, Y. Biogeochemical Sulfur Cycling Coupling with Dissimilatory Nitrate Reduction Processes in Freshwater Sediments. Environ. Rev. 2018, 26, 121-132. [CrossRef]

51. Schlesinger, W.H.; Bernhardt, E.S. Biogeochemsitry: An Analysis of Global Change, 3rd ed.; Wiley: New York, NY, USA, 2013.

52. Raghoebarsing, A.A.; Arjan, P.; Pas-Schoonen, K.T.; van de Smolders, A.J.P.; Ettwig, K.F.; Rijpstra, W.I.C.; Stefan, S.; Damsté, J.S.S.; op den Camp, H.J.M.; Jetten, M.S.M. A Microbial Consortium Couples Anaerobic Methane Oxidation to Denitrification. Nature 2006, 440, 918-921. [CrossRef] [PubMed]

53. Blair, N.E.; Aller, R.C. Anaerobic Methane Oxidation on the Amazon Shelf. Geochim. Cosmochim. Acta 1995, 59, 3707-3715. [CrossRef]

54. Wrage, N.; Velthof, G.L.; Beusichem, M.L.V.; Oenema, O. Role of Nitrifier Denitrification in the Production of Nitrous Oxide. Soil Biol. Biochem. 2001, 33, 1723-1732. [CrossRef]

55. Li, C.S. Modeling Trace Gas Emissions from Agricultural Ecosystems. Nutr. Cycl. Agroecosys. 2000, 58, 259-276. [CrossRef]

56. Avery, G.B.; Shannon, R.D.; White, J.R.; Martens, C.S.; Alperin, M.J. Controls on Methane Production in a Tidal Freshwater Estuary and a Peatland: Methane Production Via Acetate Fermentation and $\mathrm{Co}_{2}$ Reduction. Biogeochemsitry 2003, 62, 19-37. [CrossRef]

57. Meirong, W.; Rui, Z.; Jun, Z.; Xinxin, X.; Xiaoyu, Y.; Zhiying, Y.; Mingmin, G.; Tao, Z. Effect of Temperature on Methanogens Metabolic Pathway and Structures Predominant Bacteria. J. Chem. Ind. Eng. 2014, 65, 1602-1606.

58. Trumbore, S.E.; Chadwick, O.A.; Amundson, R. Rapid Exchange between Soil Carbon and Atmospheric Carbon Dioxide Driven by Temperature Change. Science 1996, 272, 393-396. [CrossRef]

59. Zehnder, A.J.; Stumm, W. Biology of Anaerobic Microorganisms; Wiley: New York, NY, USA, 1988.

60. Yue, X.P.; Fu, M.H.; Li, Y.X.; Cao, J.Z. Effect of Influent Alkalinty on Anaerobic Sequencing Batch Reactor. J. Chem. Ind. Eng. 2008, 59, 1257-1263.

61. González, J.S.; Rivera, A.; Borja, R.; Sánchez, E. Influence of Organic Volumetric Loading Rate, Nutrient Balance and Alkalinity: COD Ratio on the Anaerobic Sludge Granulation of an Uasb Reactor Treating Sugar Cane Molasses. Inter. Biodeter. Biodegrad. 1998, 41, 127-131. [CrossRef]

62. Stocker, T.F.; Qin, D.; Plattner, G.K. Climate Change 2013: The Physical Science Basis. Contribution of Working Group I to the Fifth Assessment Report of the Intergovernmental Panel on Climate Change; Cambridge University Press: Cambridge, UK, 2013.

63. Gauci, V.; Chapman, S.J. Simultaneous Inhibition of Ch 4 Efflux and Stimulation of Sulphate Reduction in Peat Subject to Simulated Acid Rain. Soil Biol. Biochem. 2006, 38, 3506-3510. [CrossRef]

64. Dise, N.B.; Verry, E.S. Suppression of Peatland Methane Emission by Cumulative Sulfate Deposition in Simulated Acid Rain. Biogeochemsitry 2001, 53, 143-160. [CrossRef]

65. Wang, L.; Wang, Y.; Cheng, H.M.; Cheng, J.L. Identifying the Driving Factors of Black Bloom in Lake Bay through Bayesian Lasso. Int. J. Environ. Res. Pub. Health 2019, 16, 2492. [CrossRef] [PubMed] 